\title{
Pengaruh Upah Minimum, PDRB dan Jumlah Industri Terhadap Penyerapan Tenaga Kerja Sektor Industri Di Karesidenan Madiun Pada Tahun 2017-2020
}

\author{
Amin Widyaningrum ${ }^{1}$, Selfia Bintariningtyas ${ }^{2}$ \\ ${ }^{1}$ Program Studi Ekonomi Pembangunan, Universitas Sebelas Maret, Jl. Ir. Sutami 36A Surakarta, 57126 \\ E-mail: awidyan@student.uns.ac.id \\ ${ }^{2}$ Program Studi Ekonomi Pembangunan, Universitas Sebelas Maret, Jl. Ir. Sutami 36A Surakarta, 57126 \\ Email: selfia.bintari@staff.uns.ac.id
}

\begin{abstract}
The purpose of this research is to determine the effect of the Minimum Wage, PDRB, and the Amount of Industry on the Absorption of Manpower in the Industrial Sector in the Madiun Residency in 2017-2020. This study uses quantitative research through secondary data from related agencies, namely the Central Statistics Agency (BPS) of East Java Province. While the analytical method used is panel data regression analysis. Based on the results of the study, it shows that the minimum wage variable has a significant negative effect on the employment in the industrial sector in the Madiun Residency, PDRB has a significant positive effect on the employment in the industrial sector in the Madiun Residency and the Amount of Industry has a positive and insignificant effect on employment in the industrial sector in the Madiun Residency.
\end{abstract}

Keywords—: Employment; Industrial Sector; Minimum Wages; PDRB; Amount of Industry.

\section{PENDAhuluan}

Penyerapan tenaga kerja di Indonesia merupakan salah satu masalah yang sampai saat ini masih menjadi permasalahan yang belum terselesaikan. Semakin bertambah jumlah pencari kerja tidak sebanding dengan tersediannya jumlah lapangan pekerjaan. Keterbatasan daya serap perekonomian terkait adanya masalah ketenagakerjaan di Indonesia dengan adanya jumlah angkatan kerja yang setiap tahunnya terus meningkat. Adanya jumlah penduduk yang semakin bertambah akan mengakibatkan peningkatan jumlah angkatan kerja. Artinya jumlah orang yang mencari kerja akan semakin banyak. Agar tercapai keseimbangan para pencari kerja dapat ditampung dengan pekerjaan yang sesuai keahlian dan keinginan mereka. Maka adanya perluasan lapangan pekerjaan diharapkan dapat menurunkan tingkat pengangguran yang ada di Indonesia (Mulyadi, 2003).

Salah satu penyebab pesatnya pertambahan angkatan kerja adalah pertambahan jumlah penduduk. Menurut data BPS (2020), Jawa Timur memiliki 22,26 juta angkatan kerja pada Agustus 2020 atau 396,37 ribu meningkat 1,81\% dari Agustus 2019. Per Agustus 2019, sebesar 21,87 juta angkatan kerja. Adanya kenaikan angka Tingkat Partisipasi Angkatan Kerja (TPAK) sebesar 0,72 poin. Berdasarkan data BPS Jawa Timur tahun lalu, tingkat pengangguran meningkat sebesar 466,02 ribu dan tingkat pengangguran terbuka (TPT) pada Agustus 2020 mencapai 5,84\% menjadi 2,02 persen. Persentase penduduk berusia 25-54 tahun yang bekerja terhadap total penduduk berusia 25-54 tahun mencapai nilai yang tertinggi dibandingkan dua kelompok usia lainnya. Penduduk yang bekerja usia 25-54 tahun sebagian besar merupakan penduduk yang sudah berkeluarga sehingga pada usia tersebut adanya tanggung jawab dalam menghidupi keluarganya. Dalam Riadi (2018) kenaikan pendapatan nasional dapat diperoleh dari jumlah penduduk suatu negara yang seimbang dengan jumlah sumber-sumber ekonominya. Menurut Mulyadi (2003), Jumlah penduduk tidak terlampau sedikit tetapi juga tidak boleh terlampau banyak.

Adanya peningkatan kegiatan ekonomi melalui angkatan kerja yang banyak diharapkan dapat meningkatan kesejahteraan rakyat. Menurut Rochmani, Purwaningsih, \& Suryantoro (2016), hubungan antara upah dan jumlah pekerja mempengaruhi pengusaha dalam menentukan jumlah pekerja yang dibutuhkan. Pemerintah diharapkan dapat melakukan upaya-upaya untuk mengatasi masalah ketenagakerjaan salah satunya yaitu dengan memperbaiki sistem upah tenaga kerja dengan kebijakan upah minimum. Adanya permintaan pasar tenaga kerja dipengaruhi oleh pemerintah daerah dalam menerapkan upah minimum. Penyerapan tenaga kerja dipengaruhi oleh adanya tingkatan upah, apabila adanya peningkatan tingkat upah maka akan mengalami penurunan angka tenaga kerja dan juga sebaliknya, jika adanya peningkatan tenaga kerja maka tingkat upah juga akan menurun (Ferdinandus, 2014)

Menurut Feriyanto (2014), Faktor dari Produk Domestik Regional Bruto adalah nilai tambah barang jasa dan dihasilkan oleh suatu industri atau sektor produksi di suatu wilayah dan selama periode tertentu. Dengan demikian asumsi bahwa peningkatan total nilai tambah output atau pendapatan semua unit ekonomi di wilayah tersebut juga meningkatkan nilai PDRB, jumlah angkatan kerja dapat mempengaruhi PDRB. Memotivasi bisnis untuk meningkatkan permintaan tenaga kerja dapat meningkatkan output. Dampak perubahan permintaan tenaga kerja di satu sektor juga mempengaruhi sektor lainnya. 
Website : http://ekomaks.unmermadiun.ac.id

Dalam memperluas lapangan pekerjaan dengan perluasan dan pemerataan pada tingkat taraf hidup yang rendah dapat menyerap banyak tenaga kerja dengan produktivitas yang rendah pada industri kecil (Malik, 2013). Adanya industri dapat membantu kesejahteraan masyarakat agar dapat mencukupi kehidupannya. Sehingga, adanya pembangunan pada sektor industri dapat membantu dalam memberikan lapangan pekerjaan bagi masyaraat yang belum mempunyai pekerjaan atau yang sedang mencari pekerjaan. Banyaknya jumlah usaha sektor industri membuat pilihan kerja juga semakin banyak seperti perusahaan atau pabrik. Maka lowongan pekerjaan juga akan semakin meningkat tinggi. Klasifikasi pengelompokan industri dapat dibagi menjadi tiga kategori meliputi industri kecil, industri sedang, dan industri besar. Data yang diperoleh dari Direktorat industri sedang dan besar menurut Kabupaten/Kota yang ada di Jawa Timur, jumlah industri di Karesidenan Madiun terbanyak pertama yaitu pada industri makanan dengan jumlah 37 unit, sedangkan jumlah industri terbanyak kedua yaitu pada industri barang galian bukan logam dengan jumlah 16 unit.

\section{Tujuan Penelitian}

Berdasarkan rumusan masalah tersebut maka tujuan dari penelitian ini adalah :

1. Untuk menjelaskan pengaruh upah minimum terhadap penyerapan tenaga kerja pada sektor industri di Karesidenan Madiun pada tahun 2017-2020?

2. Untuk menjelaskan pengaruh PDRB terhadap penyerapan tenaga kerja pada sektor industri di Karesidenan Madiun pada tahun 2017-2020?

3. Untuk menjelaskan pengaruh jumlah industri terhadap penyerapan tenaga kerja pada sektor industri di Karesidenan Madiun pada tahun 2017-2020?

\section{TINJAUAN TEORITIS}

\section{A. Penyerapan Tenaga Kerja}

Penyerapan tenaga kerja adalah jumlah pekerjaan yang terpenuhi, termasuk banyaknya tenaga kerja. Penyerapan penduduk dan distribusi perekonomian ke sektor lain berasal dari jumlah tenaga kerja yang banyak (Kuncoro, 2002). Di banyak sektor ekonomi, penyerapan penduduk disebabkan oleh permintaan tenaga kerja. Sehingga, faktor yang berpengaruh pada permintaan tenaga kerja juga mempengaruhi proses penyerapan pada tenaga kerja.

B. Upah Minimum

Upah minimum adalah standar minimum yang dipakai pengusaha dan perusahaan industri untuk memberikan upah kepada para pekerja di dunia usaha dan kerja. Sedangkan menurut Peraturan Menteri Tenaga Kerja dan Transmigrasi Nomor 7 tahun 2013, upah minimum adalah upah minimum yang ditetapkan oleh gubernur sebagai jaring pengaman untuk melindungi pekerja. Atau, upah minimum dapat dibagi menjadi Upah Minimum Provinsi (UMP) dan Upah Minimum Kabupaten/Kota (UMK). Kepribadian dan dinamika yang semakin kompleks, kondisi kerja memaksa pemerintah untuk mengatur upah pekerja. Upah minimum ini biasanya ditentukan oleh pemerintah (Gubernur memperhitungkan komisi pengupahan Negara dan/atau rekomendasi bupati/walikota), dan berubah setiap tahun tergantung perubahan sesuai tujuan ditetapkannya upah minimum.

C. PDRB

Menurut Badan Pusat Statistik (BPS), Produk domestik regional bruto merupakan jumlah nilai tambah yang diciptakan oleh semua unit produksi di daerah tersebut selama periode tertentu, atau jumlah barang dan jasa yang dihasilkan oleh semua unit produksi tersebut. PDRB merepresentasikan kemampuan suatu daerah untuk mengelola sumber daya alam. Dengan demikian, penghasilan nilai PDRB di setiap wilayah bergantung pada potensi faktor produksi di daerah tersebut.

\section{Jumlah Industri}

Menurut pasal 3 Undang-Undang Republik Indonesia Pasal 1 tahun 2014, industri adalah segala sesuatu yang mengolah bahan mentah dan menggunakan sumber daya industri untuk menghasilkan barang yang bernilai atau keuntungan lebih tinggi, termasuk jasa industri ini adalah salah satu bentuk kegiatan ekonomi.

Menurut Badan Pusat Statistik (BPS) industri atau perusahaan adalah suatu unit usaha yang melakukan kegiatan ekonomi yang bertujuan untuk menghasilkan barang dan jasa, yang terletak pada suatu bangunan atau tempat tertentu, dan mempunyai profil pengelolaan tersendiri. Produksi atau biaya serta ada seorang yang bertanggung jawab atas usaha tersebut. Berdasarkan BPS, Sektor industri dapat dibagi menurut jumlah tenga kerja yang ada dalam proses produksi dan dapat dibagi menjadi empat :

1. Industri rumah tangga : jumlah tenaga kerja yang dipekerjakan dalam proses produksi adalah 1-4 orang. Contoh : industri tekstil, industri kerajinan, industri tempe/ tahu, dan industri makanan ringan.

2. Industri kecil : jumlah tenaga kerja yang dipekerjakan dalam proses produksi adalah 5-19 orang. Contoh : industri genteng, industri batubata, dan industri pengolahan rotan.

3. Industri sedang : jumlah tenaga kerja yang dipekerjakan dalam proses produksi adalah 20-99 orang. Contoh : industri konveksi, industri border, dan industri keramik.

4. Industri besar : jumlah tenaga kerja yang dipekerjakan dalam proses produksi adalah 100 orang atau lebih. Contoh : industri tekstil, industri otomotif, industri besi baja, dan industri penerbangan. 
Website : http://ekomaks.unmermadiun.ac.id

\section{E. Penelitian Terdahulu}

Rochmani, Purwaningsih, \& Suryantoro (2016) dengan judul Analisis Penyerapan Tenaga Kerja Sektor Industri Di Provinsi Jawa Tengah. Tujuan penelitian ini yaitu mengetahui pengaruh pertumbuhan ekonomi di Provinsi Jawa Tengah, upah minimum kota/kabupaten (UMK) dan jumlah unit usaha industri terhadap penyerapan tenaga kerja di Jawa Tengah. Metode analisis ini yaitu regresi data panel menggunakan pemodelan persamaan regresi. Pada penelitian ini adanya variabel pertumbuhan ekonomi, upah minimum Kabupaten/kota dan jumlah unit usaha industri secara bersama-sama mempengaruhi penyerapan tenaga kerja di Jawa Tengah.

Ardiansyah, Zuhroh, \& Abdullah (2018) menggunakan judul Analisis Penyerapan Tenaga Kerja Sektor Industri Pengolahan Tahun 2001-2015 Di Pasuruan Dan Sidoarjo. Tujuan pada penelitiannya adalah untuk mengetahui dan membandingkan pengaruh jumlah unit usaha, upah minimum dan pertumbuhan ekonomi terhadap penyerapan tenaga kerja sektor industri pengolahan di Kabupaten Sidoarjo dan Kabupaten Pasuruan. Metode analisis dalam penelitian ini adalah regresi linier berganda dengan menggunakan data time series. Hasil penelitian ini menunjukkan bahwa jika F-hitung $>$ Ftabel adalah Kabupaten Pasuruan sebesar 679.4531 > 3.59, dan jika dari Kabupaten Sidoarjo $27.85815>3.59$ (Uji F). Kabupaten Sidoarjo dan Kabupaten Pasuruan secara individual berpengaruh positif dan signifikan terhadap Penyerapan Tenaga Kerja berdasarkan jumlah unit usaha, dan berpengaruh negatif signifikan terhadap penyerapan tenaga kerja menurut jumlah unit usaha. Upah minimum, serta pengaruhnya yang positif dan signifikan terhadap pertumbuhan ekonomi berpengaruh positif signifikan terhadap tingkat penyerapan tenaga kerja.

Firdaus (2018), dalam judul penelitian Analisis Penyerapan Tenaga Kerja Di Indonesia. Tujuan dari penelitian ini yaitu mengetahui tingkat penyerapan tenaga kerja di 33 Provinsi di Indonesia. Metode dalam penelitian ini yaitu analisis data panel dengan menggunakan model regresi fixed-effect. Hasil penelitian ini menunjukkan bahwa variabel UMP dan Investasi berpengaruh negatif. Sementara itu, variabel PDRB dan Jumlah Industri Besar Menengah berpengaruh positif terhadap adanya penyerapan jumlah tenaga kerja di Indonesia.

Zenda (2017), judul penelitiannya Peranan Sektor Industri terhadap Penyerapan Tenaga Kerja di Kota Surabaya. Tujuan dari penelitian ini yaitu untuk menunjukkan bahwa terdapat pengaruh positif signifikan terhadap ketenagakerjaan di Kota Surabaya. Metode dari pengambilan sampelnya yaitu menggunakan data time series. Penelitian ini terdiri dari jenis penelitian deskriptif kuantitatif dengan menggunakan teknik analisis regresi linier. Hasil penelitian ini menunjukkan bahwa penyerapan tenaga kerja di Surabaya berdampak signifikan terhadap jumlah industri.

Mehic (2018), judul penelitian Industrial employment and income. Tujuan penelitian ini yaitu mengetahui pengaruh pekerjaan di sektor industri terhadap kesenjangan pendapatan di 27 negara dari tahun 1991 hingga tahun 2014. Hasil penelitian ini menunjukkan bahwa lapangan kerja sektor industri memiliki pengaruh signifikan pada ketimpangan pendapatan.

\section{III.METODE PENELITIAN}

Metode Penelitian ini yakni menggunakan penelitian kuantitaf. Penelitian ini dengan data sekunder dari instansi terkait yaitu BPS Provinsi Jawa Timur tahun 2017-2020. Pengumpulan data menggunakan teknik dokumentasi yaitu teknik pengumpulan data dari berbagai literature seperti jurnal serta informasi tertulis dan berasal dari instansi yang terkait dalam topik penelitian. Variabel dalam penelitian ini meliputi variabel dependen yakni Penyerapan Tenaga Kerja Sektor Industri dan variabel independen yakni Upah Minimum, PDRB dan Jumlah Industri di Karesidenan Madiun tahun 2017-2020.

Bentuk persamaan model data panel dalam penelitian ini sebagai berikut :

Dimana :

$$
\text { Yit }=\beta 0+\beta_{1} X_{1 i t}+\beta_{2} X_{2 i t}+\beta_{3} X_{3 i t}+e_{i t}
$$

$\begin{array}{ll}\mathrm{Y} & \text { : Penyerapan Tenaga Kerja } \\ \beta 0 & \text { : Konstanta/Intercept } \\ \beta 1, \beta 2, \beta 3 & \text { : Koefisien Regresi Parsial } \\ \mathrm{X} 1 & \text { : Upah Minimum } \\ \mathrm{X} 2 & \text { : PDRB Sektor Industri } \\ \mathrm{X} 3 & \text { : Jumlah Industri } \\ \mathrm{e} & \text { : Error term } \\ \mathrm{i} & \text { : Data cross section } 6 \text { Kota/Kabupaten } \\ \mathrm{t} & \text { : Data time series } 4 \text { tahun 2017-2020 }\end{array}$

Dikarenakan persamaan dalam bentuk non-linier, maka diubah ke bentuk logaritma menjadi linier. Oleh karena itu, maka memiliki persamaan seperti berikut :

$$
L O G \_Y i t=\beta 0+\beta_{1} L O G \_X 1 i t+\beta_{2} L O G \_X 2 i t+\beta_{3} L O G \_X_{3 i t}+e_{i t}
$$


Website : http://ekomaks.unmermadiun.ac.id

Langkah selanjutnya dalam menentukan pengaruh variabel independen terhadap variabel dependen adalah dengan menggunakan uji asumsi klasik, uji F (uji simultan), uji t (uji parsial), dan koefisien determinasi (Adjusted R-Square).

\section{IV.ANALISIS DAN PEMBAHASAN}

\section{Gambar Data Penelitian}

Penduduk pada suatu Negara bisa dibedakan menjadi 2 golongan yaitu golongan tenaga kerja dan golongan bukan tenaga kerja. Golongan yang menjadi tenaga kerja merupakan penduduk pada usia kerja dan yang tidak tergolong tenaga kerja yaitu penduduk yang belum termasuk usia kerja. Maka jumlah tenaga kerja sektor industri di Karesidenan Madiun tahun 20172020 dapat dilihat pada Tabel 1.

Tabel 1. Jumlah Tenaga Kerja Sektor Industri di Karesidenan Madiun tahun 2017-2020 (Jiwa)

\begin{tabular}{ccccc}
\hline Kab/Kota & $\mathbf{2 0 1 7}$ & $\mathbf{2 0 1 8}$ & $\mathbf{2 0 1 9}$ & $\mathbf{2 0 2 0}$ \\
\hline Kota Madiun & 5147 & 3746 & 5139 & 1984 \\
\hline Kab Madiun & 2462 & 2636 & 2522 & 2484 \\
\hline Kab Magetan & 3602 & 5540 & 3495 & 2086 \\
\hline Kab Ngawi & 6512 & 5760 & 6751 & 1989 \\
\hline Kab Pacitan & 3093 & 3364 & 3103 & 3565 \\
\hline Kab Ponorogo & 1864 & 1852 & 1866 & 13.701 \\
\hline Jumlah & 22.680 & 22.898 & 22.876 & \\
\hline Sumber: BPS Kab/Kota Karesidenan Madiun & & &
\end{tabular}

Berdasarkan tabel diatas, menjelaskan bahwa jumlah penyerapan tenaga kerja yang saat ini sedang bekerja pada tahun 2017 sampai 2020 di Kabupaten/Kota Karesidenan Madiun mengalami peningkatan dari tahun 2017 sampai 2020 dan mengalami penurunan pada tahun 2020. Pada tahun 2017 dengan jumlah 22.680 jiwa, tahun 2018 berjumlah 22.898 jiwa, tahun 2019 berjumlah 22.876 jiwa dan mengalami penurunan pada tahun 2020 berjumlah 13.701 jiwa.

Selanjutnya data tentang penetapan upah minimum harus lebih tinggi dari upah minimum provinsi. Pada peraturan Gubernur Jawa Timur setiap tahun didapat upah minimum kabupaten/kota di wilayah Karesidenan Madiun yang terlihat pada Tabel 2 adalah :

Tabel 2. Jumlah Upah Minimum Kab/Kota Karesidenan Madiun Tahun 2017-2020 (Rupiah)

\begin{tabular}{ccccc}
\hline Kab/Kota & $\mathbf{2 0 1 7}$ & $\mathbf{2 0 1 8}$ & $\mathbf{2 0 1 9}$ & $\mathbf{2 0 2 0}$ \\
\hline Kota Madiun & 1509005 & 1640439 & 1801406 & 1954705 \\
\hline Kab. Madiun & 1450550 & 1576893 & 1763267 & 1913321 \\
\hline Kab. Magetan & 1388847 & 1509816 & 1763267 & 1913321 \\
\hline Kab. Ngawi & 1444055 & 1569832 & 1763267 & 1913321 \\
\hline Kab. Pacitan & 1388847 & 1509816 & 1763267 & 1913321 \\
\hline Kab. Ponorogo & 1388847 & 1509816 & 1763267 & 1913321 \\
\hline Sumber : BPS Kab/Kota Karesidenan Madiun & & &
\end{tabular}

Kenaikan upah terjadi karena adanya peran pemerintah dalam menetapkan Upah Minimum Kabupaten/Kota (UMK) untuk mengurangi kemiskinan dan ketimpangan pendapatan. Adanya kenaikan Upah Minimum Kabupaten/Kota membuktikan dapat menurunkan angka kemiskinan dan menurunkan ketimpangan pendapatan di beberapa daerah di Jawa Timur khususnya wilayah Karesidenan Madiun. Sementara itu, Menurutt BPS (2020) PDRB merupakan indikator yang dapat digunakan untuk mengukur aktivitas ekonomi di daerah. Keberadaan Sektor industri pengolahan mampu menyerap angkatan kerja baru, Perkembangan sektor industri tidak hanya ditandai dengan peningkatan produksi, tetapi juga semakin beragamnya jenis produk yang diproduksi. Berikut perkembangan PDRB Atas Dasar Harga Konstan pada sektor industri di Karesidenan Madiun dari tahun 2017-2020 dapat dilihat pada Tabel 3.

Tabel 3. PDRB Sektor Industri di Karesidenan Madiun Tahun 2017-2020 (Miliar)

\begin{tabular}{ccccc}
\hline Kab/Kota & $\mathbf{2 0 1 7}$ & $\mathbf{2 0 1 8}$ & $\mathbf{2 0 1 9}$ & $\mathbf{2 0 2 0}$ \\
\hline Kota Madiun & 1677,6 & 1795,2 & 1878,5 & 1637,3 \\
\hline Kab. Madiun & 1231,3 & 1351,3 & 1448,4 & 1427,9 \\
\hline Kab. Magetan & 1215,6 & 1347,1 & 1451,3 & 1423,4 \\
\hline Kab. Ngawi & 1064,5 & 1140,1 & 1207,3 & 1150,5 \\
\hline Kab. Pacitan & 682 & 735,7 & 779,1 & 727 \\
\hline Kab. Ponorogo & 923,5 & 993,5 & 1063,8 & 1078,6 \\
\hline Sumber : BPS Jawa Timur & & & &
\end{tabular}


Website : http://ekomaks.unmermadiun.ac.id

Kegiatan perekonomian di setiap Kabupaten/Kota di Jawa Timur khususnya di Karesidenan Madiun dapat berkembang dengan baik dan dapat berkontribusi dalam Produk Domestik Regional Bruto (PDRB) dari pendapatan yang diterima dari hasil kegiatan ekonomi khususnya pada sektor industri. Adanya peningkatan jumlah industri terjadi karena pada dasarnya Provinsi Jawa Timur yang strategis terutama di sektor industri dan kawasan karesidenan Madiun juga dapat dijadikan sebagai pusat pertumbuhan industri dan perdagangan. Daerah di Karesidenan Madiun mempunyai unggulan pada sektor industri masingmasing, sehingga dapat menjadi penggerak pembangunan ekonomi dalam penyerapan tenaga kerja yang dapat mengurangi pengangguran di Karesidenan Madiun. Perkembangan jumlah unit usaha menurut direktori perusahaan besar dan sedang provinsi jawa timur tahun 2017-2020 disajikan pada Tabel 4.

Tabel 4. Jumlah Industri Besar Sedang di Karesidenan Madiun Tahun 2017-2020 (Unit)

\begin{tabular}{ccccc}
\hline Kab/Kota & $\mathbf{2 0 1 7}$ & $\mathbf{2 0 1 8}$ & $\mathbf{2 0 1 9}$ & $\mathbf{2 0 2 0}$ \\
\hline Kota Madiun & 58 & 31 & 29 & 20 \\
\hline Kab. Madiun & 24 & 23 & 18 & 25 \\
\hline Kab. Magetan & 37 & 30 & 23 & 31 \\
\hline Kab. Ngawi & 27 & 19 & 18 & 20 \\
\hline Kab. Pacitan & 17 & 26 & 19 & 16 \\
\hline Kab. Ponorogo & 34 & 47 & 48 & 36 \\
\hline Sumber : BPS Jawa Timur & & &
\end{tabular}

\section{Pengujian Hipotesis}

a. Uji F

Tabel 5. Hasil Uji F

\begin{tabular}{cc}
\hline Nilai Prob(F-statistic) & Kesimpulan \\
\hline 0.004491 & Sig \\
\hline Sumber: Data Sekunder, data diolah &
\end{tabular}

Berdasarkan uji $\mathrm{F}$ tersebut, maka dapat diasumsikan bahwa variabel independen yakni upah minimum, PDRB industri dan jumlah industri dapat bersama-sama mempengaruhi variabel dependen yakni tingkat penyerapan tenaga kerja sektor industri secara signifikan.

b. Uji T

Tabel 6. Hasil Uji T

\begin{tabular}{cccc}
\hline Variable & Coefficient & Prob. & Keterangan \\
\hline LOG_UMK & -2.841591 & 0.0049 & Signifikan \\
\hline LOG_PDRB & 4.954777 & 0.0050 & Signifikan \\
\hline LOG_INDUSTRI & 0.169183 & 0.6073 & Tidak Signifikan \\
\hline
\end{tabular}

Sumber: Data Sekunder, data diolah

- Variabel independen upah minimum (UMK) memiliki nilai probabilitasnya sebesar $0.0049<$ tingkat signifikansi $\alpha$ $(0,05)$. Maka Ho ditolak yang artinya dapat diambil kesimpulan bahwa tingkat signifikansi alpha $5 \%$ variabel independen penyerapan tenaga kerja sektor industri secara individu berpengaruh signifikan terhadap variabel dependen penyerapan tenaga kerja sektor industri di Karesidenan Madiun pada tahun 2017-2020.

- Variabel independen PDRB Sektor Industri memiliki nilai probabilitasnya sebesar $0.0050<$ tingkat signifikansi $\alpha$ $(0,05)$. Maka Ho ditolak yang artinya dapat diambil kesimpulan bahwa tingkat signifikansi alpha 5\% variabel independen penyerapan tenaga kerja sektor industri secara individu berpengaruh signifikan terhadap variabel dependen penyerapan tenaga kerja sektor industri di Karesidenan Madiun pada tahun 2017-2020.

- Variabel independen Jumlah Industri memiliki nilai probabilitasnya sebesar $0.6073>$ tingkat signifikansi $\alpha(0,05)$. Maka Ho diterima yang artinya memiliki kesimpulan adanya tingkat signifikansi alpha 5\% variabel independen penyerapan tenaga kerja sektor industri secara individu tidak berpengaruh signifikan terhadap variabel dependen penyerapan tenaga kerja sektor industri di Karesidenan Madiun pada tahun 2017-2020.

c. Koefisien Determinasi $\left(\mathrm{Uji}^{2}\right)$

\begin{tabular}{lc}
\multicolumn{2}{c}{ Tabel 7. Hasil Uji $\mathrm{R}^{2}$} \\
\hline Adjusted $R$-squared & 0.718393 \\
\hline Sumber: Data Sekunder, data diolah
\end{tabular}

Berdasarkan hasil penelitian diatas, maka didapatkanlah nilai Adjusted R- squared sebesar 0,71 (71\%), artinya mampu menjelaskan penyerapan tenaga kerja sebesar $71 \%$. Sedangkan, sisanya $29 \%$ dijelaskan oleh variabel selain yang digunakan di penelitian ini.

\section{Hasil Analisis}


Website : http://ekomaks.unmermadiun.ac.id

Model yang terpilih pada penelitian ini adalah model fixed effect model (FEM), dibawah ini adalah hasil regresi data panel menggunakan eviews 10. Hasil analisis regresi tersebut terdapat pada tabel 5.

Tabel 5. Hasil Analisis Regresi Data Panel

Fixed Effect Model

\begin{tabular}{ccc}
\multicolumn{3}{c}{ Fixed Effect Model } \\
\hline C & Coefficient & Probabilitas \\
\hline LOG_UMK & 13.13295 & 0.1827 \\
\hline LOG_PDRB & -2.841591 & 0.0049 \\
\hline LOG_INDUSTRI & 4.954777 & 0.0050 \\
\hline \multicolumn{2}{r}{ R-squared } & 0.6073 \\
\hline \multicolumn{2}{r}{ Adjusted R-squared } & 0.718393 \\
\hline \multicolumn{2}{r}{ Prob $(\boldsymbol{F}$-statistic) } & 0.568202 \\
\hline
\end{tabular}

Sumber: Data Sekunder, data diolah

Dari hasil analisis diatas maka didapatkanlah persamaan sebagai berikut :

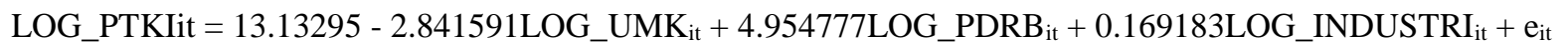

a. Pengaruh upah minimum terhadap penyerapan tenaga kerja sektor industri di Karesidenan Madiun tahun 2017-2020

Berdasarkan hasil dari regresi data panel melalui pendekatan model fixed effect model (FEM) diatas menunjukan nilai probabilitas upah minimum (UMK) sebesar 0.0049 dengan nilai koefisiensi -2.841591. Dari nilai probabilitas tersebut menunjukkan bahwa upah minimum berpengaruh signifikan secara statistik terhadap tingkat penyerapan tenaga kerja sektor industri. Kemudian dengan nilai koefisien dapat menunjukan adanya hubungan negatif, artinya jika variabel independen (UMK) mengalami kenaikan sebesar $1 \%$ maka variabel dependen (tingkat penyerapan tenaga kerja sektor industri) akan mengalami penurunan sebesar $0.005 \%$.

Hasil dari studi ini memiliki kesamaan dengan hasil penelitian yang dilakukan oleh (Ardiansyah, Zuhroh, \& Abdullah (2018), yang mana menghasilkan kesimpulan yaitu variabel upah minimum berpengaruh negatif signifikan, termasuk variabel penyerapan tenaga kerja sektor industri sedang dan besar pada tahun 2001 sampai 2015 di Kabupaten Sidoarjo. Menurut Zilfiyah (Ardiansyah, Zuhroh, \& Abdullah, 2018) Tuntutan pengusaha terhadap kenaikan upah berpengaruh negatif terhadap adanya pengangguran. Adanya peningkatan upah dapat membuat biaya produksi juga meningkat, yang mengarah pada operasi perusahaan yang tidak efisien dan adanya kebijakan pengurangan pada tenaga kerja untuk mengurangi biaya produksi. Maka menyimpulkan bahwa menaikkan upah minimum membuat jumlah tenaga kerja menjadi berkurang dan dengan demikian mengurangi jumlah untuk menyerap tenaga kerja. Sedangkan, pada penelitian Sumarsono (Rochmani, Purwaningsih, \& Suryantoro, 2016) upah mempengaruhi tingkat biaya produksi dan dapat mengurangi atau menambah jumlah tenaga kerja.

b. Pengaruh PDRB Industri terhadap penyerapan tenaga kerja sektor industri di Karesidenan Madiun tahun 2017-2020.

Berdasarkan hasil regresi data panel dengan menggunakan pendekatan fixed effect model (FEM) diatas, nilai probabilitas produk domestik regional bruto (PDRB) sektor industri sebesar 0.0050 dengan nilai koefisiensi 4.954777. Dari nilai probabilitas dapat disimpulkan bahwa upah minimum memiliki pengaruh signifikan secara statistik pada tingkat penyerapan tenaga kerja di sektor industri. Kemudian dengan nilai koefisien dapat menunjukan bahwa terdapat hubungan positif, yang mana artinya adalah jika variabel independen (PDRB) sektor industri mengalami peningkatan sebesar $1 \%$ maka variabel dependen (tingkat penyerapan tenaga kerja sektor industri) akan mengalami peningkatan $4.955 \%$.

Hasil dari studi ini sesuai dengan penelitian Wasilaputri (2016) yang menemukan bahwa PDRB memiliki pengaruh yang positif dan signifikan terhadap penyerapan tenaga kerja di Pulau Jawa tahun 2010-2014. Selanjutnya penelitian oleh Tarigan (2018) bahwa nilai PDRB pada sektor industri berpengaruh positif dan signifikan pada penyerapan tenaga kerja sektor industri di Sumatera Utara tahun 1997-2016. Riadi (2018) dengan judul Pengaruh UMR, PDRB, dan Jumlah Perusahaan Dalam Industri Manufaktur Terhadap Penyerapan Tenaga Kerja di Kabupaten/Kota di Provinsi Banten Tahun 2010-2015.

Berdasarkan teori PDRB mempengaruhi lapangan kerja. Hal ini karena PDRB adalah jumlah pendapatan yang dihasilkan oleh daerah itu sendiri, atau kemampuan daerah untuk membagi biaya faktor produksi untuk menghasilkan (nilai tambah) produksi pada waktu tertentu. Peningkatan nilai PDRB menunjukkan peningkatan nilai tambah produksi atau penjualan di semua unit ekonomi di wilayah tersebut. Semakin banyak perusahaan memproduksi atau menjual, maka semakin banyak yang dapat diproduksi sebagai respons terhadap peningkatan penjualan karena meningkatnya permintaan tenaga kerja. Peningkatan PDRB akan mendukung pertumbuhan ekonomi dan mempengaruhi pada penyerapan tenaga kerja didaerah tersebut. PDRB memiliki pengaruh positif pada penyerapan tenaga kerja, artinya jika PDRB meningkat maka begitu juga dengan tenaga kerja.

c. Pengaruh Jumlah Industri terhadap penyerapan tenaga kerja sektor industri di Karesidenan Madiun tahun 2017-2020. 
Website : http://ekomaks.unmermadiun.ac.id

Berdasarkan hasil dari regresi data panel dengan pendekatan fixed effect model diatas menunjukan nilai probabilitas Jumlah Sektor Industri sebesar 0.6073 dengan nilai koefisiensi 0.169183. Dari nilai probabilitas tersebut maka disimpulkan Jumlah Industri tidak signifikan secara statistik terhadap penyerapan tenaga kerja di sektor industri. Kemudian dengan nilai koefisien dapat menunjukan bahwa terdapat hubungan positif, yang mana artinya adalah jika variabel independen (Jumlah Industri) sektor industri mengalami kenaikan sebesar $1 \%$ maka variabel dependen (tingkat penyerapan tenaga kerja sektor industri) tidak akan mengalami kenaikan. Dengan demikian, jumlah industri berpengaruh positif terhadap penyerapan tenaga kerja di Karesidenan Madiun tetapi hasilnya tidak signifikan. Hal ini disebabkan karena banyak perusahaan sedang dan besar di wilayah Karesidenan Madiun yang sudah menggunakan teknologi modern sehingga jika jumlah industri meningkat maka tidak berpengaruh dengan penyerapan tenaga kerja yang ada di wilayah Karesidenan Madiun.

Hasil penelitian ini sesuai dengan penelitian Rochmani, Purwaningsih, \& Suryantoro (2016). Jumlah unit usaha tidak berpengaruh pada penyerapan tenaga kerja di Provinsi Jawa Tengah. Berkaitan dengan keadaan industri di Provinsi Jawa Tengah, dan ada tidaknya jumlah unit usaha tidak mempunyai pengaruh terhadap penyerapan tenaga kerja. Pada kenyataannya jumlah unit usaha yang jumlahnya terbatas mampu menyerap tenaga kerja dengan jumlah relatif banyak.

Selanjutnya penelitian oleh Gunawan \& Saputri (2018), penambahan jumlah unit usaha mempengaruhi pada penyerapan tenaga kerja secara positif terhadap sektor industri pengolahan besar dan sedang di Kota Surabaya Tahun 20052014, meskipun tidak signifikan. Hal ini disebabkan oleh fakta bahwa banyak perusahaan sudah berteknologi modern dan pengaruh jumlah unit usaha menjadi tidak signifikan pada penyerapan tenaga kerja.

\section{KESIMPULAN DAN SARAN}

\section{A. Kesimpulan}

Berdasarkan hasil analis dan pembahasan diatas maka kesimpulannya adalah sebagai berikut :

1. Upah minimum berpengaruh signifikan dan berhubungan negatif terhadap tingkat penyerapan tenaga kerja sektor industri di Karesidenan Madiun. Oleh karena itu, upah minimum tidak dapat menjadi faktor yang mempengaruhi tingkat penyerapan tenaga kerja sektor industri di Karesidenan Madiun.

2. PDRB Sektor Industri berpengaruh signifikan dan berhubungan positif terhadap tingkat penyerapan tenaga kerja sektor industri di Karesidenan Madiun. Oleh karena itu, PDRB Sektor Industri dapat menjadi faktor yang mempengaruhi tingkat penyerapan tenaga kerja sektor industri di Karesidenan Madiun.

3. Jumlah Industri memiliki pengaruh yang tidak signifikan dan berhubungan positif terhadap tingkat penyerapan tenaga kerja sektor industri di Karesidenan Madiun. Oleh karena itu, Jumlah Industri tidak dapat menjadi faktor yang mempengaruhi tingkat penyerapan tenaga kerja sektor industri di Karesidenan Madiun.

\section{B. Saran}

Berdasarkan hasil penelitian dan kesimpulan, maka saran yang diberikan oleh penulis adalah sebagai berikut :

1. Diharapkan adanya kebijakan dalam penetapan nilai upah dari pemerintah dapat meningkatkan produktivitas tenaga kerja dan meningkatkan penghasilan tenaga kerja agar terciptanya kesejahteraan pekerja.

2. Pemerintah daerah hendaknya mendukung dalam peningkatan produk domestik regional bruto khususnya pada sektor industri sehingga penyerapan tenaga kerja pada sektor ini dapat meningkat.

3. Pemerintah Pusat dan Daerah sebaiknya lebih memperhatikan dalam pengembangan sektor industri agar adanya pertumbuhan angkatan kerja yang lebih baik dan mengutamakan dalam penyerapan tenaga kerja lokal yang ada di Karesidenan Madiun sehingga dapat mengurangi adanya jumlah pengangguran.

\section{VI.DAFTAR PUSTAKA}

Ardiansyah, M., Zuhroh, I., \& Abdullah, M. F. (2018). Analisis Penyerapan Tenaga Kerja Sektor Industri Pengolahan Tahun 2001-2015 Di Pasuruan dan Sidoarjo. Jurnal Ilmu Ekonomi, 2(2), 294-308. Retrieved from https://ejournal.umm.ac.id/index.php/jie/article/view/7032

BPS. (2020). Direktori Perusahaan Industri Besar dan Sedang Provinsi Jawa Timur Dalam Angka Tahun 2017-2020. Retrieved 2021, from Badan Pusat Statistik Provinsi Jawa Timur: https://jatim.bps.go.id/publication/2020/12/28/07ba141650348d31c8a75d2b/direktori-perusahaan-industri-besar-dansedang-provinsi-jawa-timur-2020.html

Ferdinandus, S. (2014). Pengaruh Tingkat Upah Dan Pertumbuhan Ekonomi Terhadap Tingkat Penyerapan Tenaga Kerja di Kota Ambon. Jurnal Benchmark, 2(3), 17-32. Retrieved from https://adoc.pub/download/abstract-pengaruh-tingkat-upah-dan-pertumbuhan-ekonomi-terha.html

Feriyanto, N. (2014). Ekonomi Sumber Daya Manusia Dalam Perspektif Indonesia. Yogyakarta: UPP STIM YKP.

Firdaus, M. (2018). Analisis Penyerapan Tenaga Kerja di Indonesia. Universitas Islam Indonesia Yogyakarta, Ilmu Ekonomi. Yogyakarta: Fakultas Ekonomi Universitas Islam Indonesia Yogyakarta. Retrieved from

https://dspace.uii.ac.id/bitstream/handle/123456789/6224/Skripsi_Muhammad\%20Firdaus\%20\%2014313201\%20PDF.pdf?sequence=1\&isAllowed $=\mathrm{y}$

Gunawan, K. I., \& Saputri, M. D. (2018). Analisis Pengaruh Jumlah Unit Usaha, Investasi Dan Upah Minimum Terhadap Penyerapan Tenaga Kerja Pada Sektor Industri Pengolahan Besar Dan Sedang Di Kota Surabaya Tahun 2005-2014. Jurnal Ekonomi dan Bisnis (JEB 17), 3(1), 589-606. Retrieved from file:///C:/Users/imut/Downloads/1346-3245-1-PB.pdf

Kuncoro, H. (2002). Upah Sistem Bagi Hasil dan Penyerapan Tenaga Kerja. Jurnal Ekonomi Pembangunan: Kajian Ekonomi Negara Berkembang, 7(1), 45-56. doi:https://doi.org/10.20885/\%25ejem.v7i1.658rt

Malik, N. (2013). Dinamika Pasar Tenaga Kerja Indonesia (1st ed). Malang: UMM Press.

Mehic, A. (2018). Industrial employment and income inequality: Evidence from panel data. Structural Change and Economic Dynamics Journal, 45(Juni), 8493. doi:https://doi.org/10.1016/j.strueco.2018.02.006v

Mulyadi. (2003). Sistem Akuntansi. Yogyakarta: STIE YKPN. 
Website : http://ekomaks.unmermadiun.ac.id

Riadi. (2018). Pengaruh UMR, PDRB, dan Jumlah Perusahaan Dalam Industri Manufaktur Terhadap Penyerapan Tenaga Kerja di Kabupaten/Kota di Provinsi Banten (Tahun 2010-2015). Universitas Islam Indonesia Yogyakarta, Program Studi Ilmu Ekonomi. Yogyakarta: Fakultas Ekonomi Universitas Islam Indonesia Yogyakarta. Retrieved from https://dspace.uii.ac.id/bitstream/handle/123456789/7537/Skripsi.pdf?sequence=1

Rochmani, T. S., Purwaningsih, Y., \& Suryantoro, A. (2016). Analisis Penyerapan Tenaga Kerja Sektor Industri Di Provinsi Jawa Tengah. Jurnal Ilmu Ekonomi dan Pembangunan (JIEP), 16(2), 50-61. doi:https://doi.org/10.20961/jiep.v16i2.2322

Tarigan, S. B. (2018). Pengaruh Investasi, PDRB dan Upah Minimum Provinsi Terhadap Penyerapan Tenaga Kerja Pada Sektor Industri Di Sumatera Utara. Universitas Sumatera Utara, Program Studi Ekonomi Pembangunan. Medan: Fakultas Ekonomi dan Bisnis Universitas Sumatera Utara. Retrieved from http://repositori.usu.ac.id/bitstream/handle/123456789/6973/140501085.pdf?sequence=1\&isAllowed=y

Wasilaputri, F. R. (2016). PENGARUH UPAH MINIMUM PROVINSI, PDRB DAN INVESTASI TERHADAP PENYERAPAN TENAGA KERJA DI PULAU JAWA TAHUN 2010-2014. Universitas Negeri Yogyakarta, Program Studi Pendidikan Ekonomi. Yogyakarta: Fakultas Ekonomi Universitas Negeri Yogyakarta. Retrieved from https://eprints.uny.ac.id/38985/1/SKRIPSI_FEBRI_12804241037.pdf

Zenda, R. H. (2017). Peranan Sektor Industri Terhadap Penyerapan Tenaga Kerja Di Kota Surabaya. Jurnal Ekonomi dan Bisnis (JEB17), 2(1), 371-384. doi:https://doi.org/10.1234/jeb17.v2i01.1097 